\title{
TISSUE-SPECIFIC PROMOTERS: THE IMPORTANCE AND POTENTIAL APPLICATION FOR GENETIC ENGINEERING IN OIL PALM
}

\author{
ZUBAIDAH, R*; NURNIWALIS, A W*; CHAN, P L*; SITI MASURA, S*; SITI NOR AKMAR, A** \\ and GHULAM KADIR AHMAD PARVEEZ*
}

\begin{abstract}
Oil palm is the most prolific oil crop in the world with a productive life span of 20-30 years and this perenniality bestows significant advantages over other oil crops. However, the industry still faces a number of challenges and to ensure its future sustainability, efforts must be made to diversify applications to increase its economic value. Amongst potential strategies include the use of genetic engineering approaches to fulfil the needs. To ensure that expression of transgenes for the production of genetically engineered products is directed to targeted tissue(s), promoter sequences that are responsible to direct the expression of desired genes have been identified. In this review we discuss the isolation and characterisation of oil palm tissue-specific promoters from mesocarp and kernel, an inducible tissue-specific promoter from roots, and the utility of constitutive promoters. The tissue-specific and constitutive functions of these promoters were confirmed through transient expression studies in oil palm and some of the isolated promoters were further characterised using Arabidopsis as a model system. We hope that these promoters can potentially be utilised to improve oil yield and quality, to fine tune the agronomic traits, and to generate high value-added products for the oil palm.
\end{abstract}

Keywords: oil palm, promoter, transient assay.

Date received: 12 April 2017; Sent for revision: 16 May 2017; Received in final form: 7 August 2017; Accepted: 12 September 2017.

\section{INTRODUCTION}

Oil palm is the main commodity crop in Malaysia and has strongly contributed to the country's economic development. However, the oil palm industry is facing several challenges notably due to the decrease in land availability for further expansion, labour shortage and competition from

\footnotetext{
* Malaysian Palm Oil Board,

6 Persiaran Institusi, Bandar Baru Bangi,

43000 Kajang, Selangor, Malaysia.

E-mail: bai@mpob.gov.my

** Laboratory of Plantation Crop,

Institute of Tropical Agriculture,

Universiti Putra Malaysia,

43400 UPM Serdang,

Selangor, Malaysia.
}

other vegetable oils. Therefore, strategies should be put in place in order to meet the current challenges and to remain competitive in future. One potential area that can be explored for improvement of oil palm profitability is by developing new and valueadded products through genetic engineering. In order to genetically engineer oil palm, a number of tools are first needed to be made available. One of the absolute prerequisites is the availability of promoter sequences to direct the expression of gene of interest in the desired tissues.

The oil palm genetic engineering programme in the Malaysian Palm Oil Board (MPOB) started in the late 1980s with the ultimate goal to produce transgenic palms containing high level of oleic acid (Cheah et al., 1995). Additionally, the programme is also aimed towards producing high value-added 
products such as industrial chemicals, nutraceuticals or even pharmaceuticals as well as novel oil/ products (Parveez et al., 1999; 2015b; Siti Nor Akmar et al., 2001; Parveez, 2003). These improvements and products would be an attractive proposition for oil palm since it is the most productive oil crop in the world (Oil World, 2013). Successful genetic modifications of the oil palm, which depends on the integration of gene(s) of interest for the targeted products into the plant nuclear genome, depends on the availability of reproducible transformation methods such as microprojectile bombardment and Agrobacterium-mediated systems. While methods for the stable introduction of transgenes are being optimised (Parveez et al., 2000; Masli et al., 2009; Masani et al., 2014), expression of foreign genes in a particular plant species requires a constitutive or tissue-specific promoter to ensure that the gene(s) will be expressed in an appropriate spatial and temporal configuration that will enhance the targeted trait. Identification of strong and tissuespecific plant promoter will ensure a more focused control of transgene expression for reducing the potential deleterious impact on normal growth and development of the plant due to ectopic transgene expression (Schaart et al., 2002).

Spatial and temporal expression of the introduced gene(s) is necessary to ensure that the gene(s) is expressed in the target tissues (mesocarp or kernel) during oil synthesis. The work on leaf- and root-specific promoters is also important especially towards the production of biodegradable plastics, development of pest- and disease-resistant palms. Without these spatial and temporal specificities, the modification would likely result in the production of target products in a less optimised manner that might be detrimental to the growth and development of the plant. Finally, constitutive promoters are also required for driving reporter or selectable marker genes which are important for the production of transgenic oil palm.

Tissue-specific promoters play a vital role in targeting gene expression carrying the desired trait for the production of 'new' products to the desired tissue. In oil palm, studies on the gene expression regulation during the course of oil synthesis in both mesocarp and kernel tissues have served as background information to isolate their promoter for genetic manipulation. To date, mesocarp- and kernel-specific candidate genes encoding type 3 metallothionein-like (MT3-A) (Siti Nor Akmar and Zubaidah, 2009), lipase class 3 (Nurniwalis et al., 2015) and glutelin (Siti Nor Akmar et al., 2014) and their corresponding promoters (Siti Nor Akmar and Zubaidah, 2009; Nurniwalis et al., 2015; Siti Nor Akmar et al., 2014) have been isolated and characterised via transient assays using $\beta$-glucuronidase (GUS), and/or green fluorescence protein (GFP) as the reporter genes, as well as in the model plant (Zubaidah and Siti Nor Akmar, 2010; Parveez et al., 2010; Hanin et al., 2016) Arabidopsis. Similarly, isolation of constitutive promoters from the oil palm genes has also been reported (Masura et al., 2010; 2011).

\section{MESOCARP-SPECIFIC PROMOTERS}

For oil palm, the fruit is the most valuable part of the plam. Oil palm fruits produce two distinct types of oil, namely, from the mesocarp and kernel tissues. The oils derived from these tissues vary in their fatty acid composition and also the duration at which the oil accumulates during oil palm fruit development. Mesocarp and kernel are storage tissues, therefore, they are suitable targets for collecting genetically engineered products without detrimental effects on the plants. Controlling both tissues by channelling the substrates and intermediates for the production of storage oil protein specifically into the tissues would be expedient. In addition, this process can lead to an alteration in the levels of existing products or to the production of novel value-added products (Mohd Basri et al., 2005). Kernel tissue, which is separated from the mesocarp by the shell, could also be used to synthesise pharmaceutically important products such as vaccines or therapeutic proteins. This is a potentially practical solution as it is physically separated from mesocarp oil and could be extracted while the kernel is still liquid without affecting or contaminating the mesocarp. The isolation of mesocarp- and kernel-specific promoters from oil palm is elaborated in the following sections.

\section{Type 3 MT3-A Promoter (MSP1)}

The MT3-A gene was identified through subtractive hybridisation on mesocarp tissue between 5 WAA (weeks after anthesis) to 15 WAA. The promoter region of MT3-A (designated MSP1: GenBank Accession No. EU499363) was isolated from Dra I genome walker library (Siti Nor Akmar and Zubaidah, 2007; 2009) and several important motifs were found in the promoter sequence including an ethylene-responsive element (EREreverse) and two I-boxes (Zubaidah and Siti Nor Akmar, 2010) and the latter motif was also found in the fruit-specific promoter of strawberry (Agius et al., 2005) and other light-regulated genes (Terzaghi and Cashmore, 1995).

The MT3-A genomic sequence consists of the promoter sequence, 3 exons, 2 introns, 5'UTR and 3'UTR (Figure 1A). A vector construct containing the MSP1 promoter and GUS reporter gene was constructed (pMT3-A:GUS) and bombarded into mesocarp slices, root and leaf disks. As a control, we also generated a GUS construct driven by constitutive promoter (CaMV $35 S$ promoter) to 
A: Structure of the MT3-A promoter
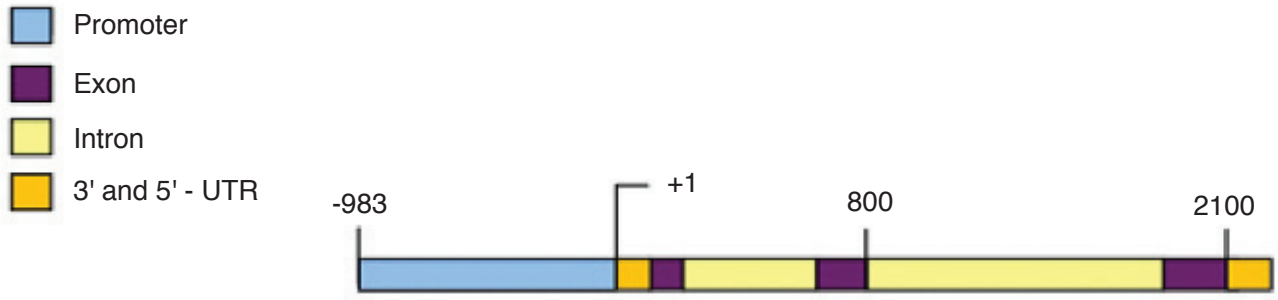

B: Transient GUS expression

Laef

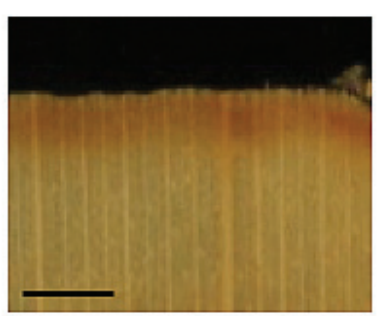

L1

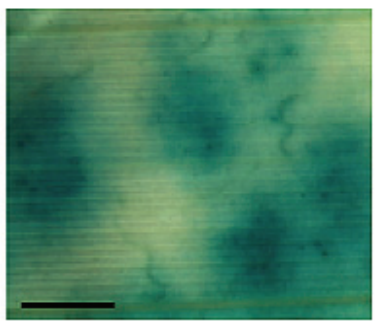

L2
Root

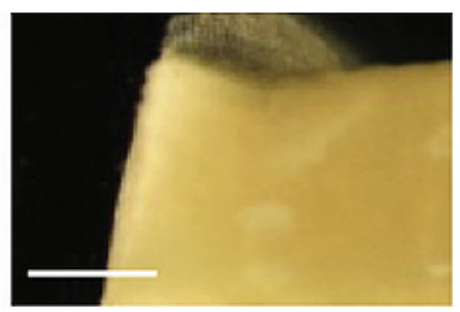

R1

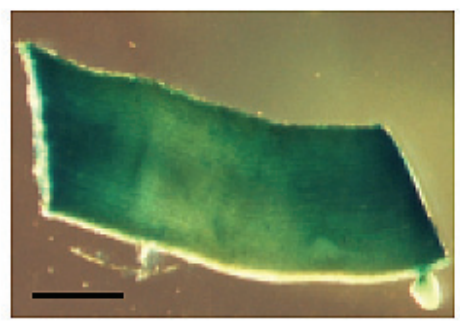

$\mathrm{R} 2$

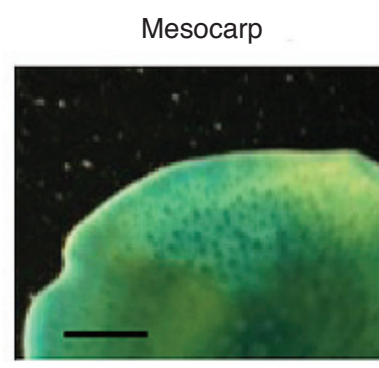

M1

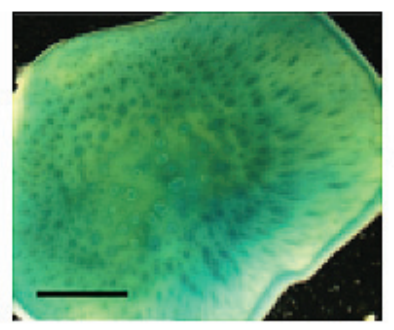

M2

MSP1

promoter

CaMV $35 S$

promoter

Figure 1. Characterisation and functional analysis of MSP1 (MT3-A) promoter. (A) Structure of the oil palm MT3-A promoter. (B) Distribution of $\beta$-glucuronidase (GUS) activity in oil palm tissues bombarded with either CaMV $35 S$ promoter::GUS ( $p$ CaMV35SGUS) or MT3-A promoter::GUS (pMT3-AGUS). Bar $=1 \mathrm{~mm}$.

yield pCaMV35SGUS plasmid. The MSP1 promoter showed mesocarp-specific activity based on the detected GUS expression (blue spots) only on bombarded mesocarp slices and not on bombarded leaf or root tissues (Figure 1B). These results provide support that activity of the MSP1 promoter is specific to mesocarp tissues.

This promoter is currently being used in the oil palm genetic engineering programme to modify the mesocarp oil composition and also for the production of novel products in the mesocarp (Masani and Parveez, 2008; Masani et al., 2008; Kamaladini et al., 2011; Omidvar et al., 2010; Parveez et al., 2015a).

\section{Lipase Class 3 (FLL1) Promoter (MSP2)}

The full-length MSP2 gene was successfully isolated following its initial identification from a 17-week-old mesocarp cDNA library (Nurniwalis et al., 2008; 2015). A 756 bp genomic sequence of MSP2 which comprises the $671 \mathrm{bp}$ of promoter sequence and $85 \mathrm{bp}$ of $5^{\prime}$ UTR was amplified using Genome walking approach (Figure 2A). The MSP2 promoter contains sequences (TATA box, pyrimidine patch, and cis-acting regulatory elements) that make up the important components of the promoter.

Transient GUS expression was conducted to evaluate the effectiveness of the MSP2 promoter to direct transgene expression to the mesocarp. A vector construct containing the MSP2 promoter and GUS reporter gene was bombarded into mesocarp slices and leaf discs. The MSP2 promoter showed mesocarp-specific activity based on detected GUS expression only on the bombarded mesocarp slices (Figure 2B) especially in the vascular bundles, and not on bombarded leaf tissues. This promoter could direct expression of foreign genes to mesocarp 
A: Structure of the (FLL1) promoter
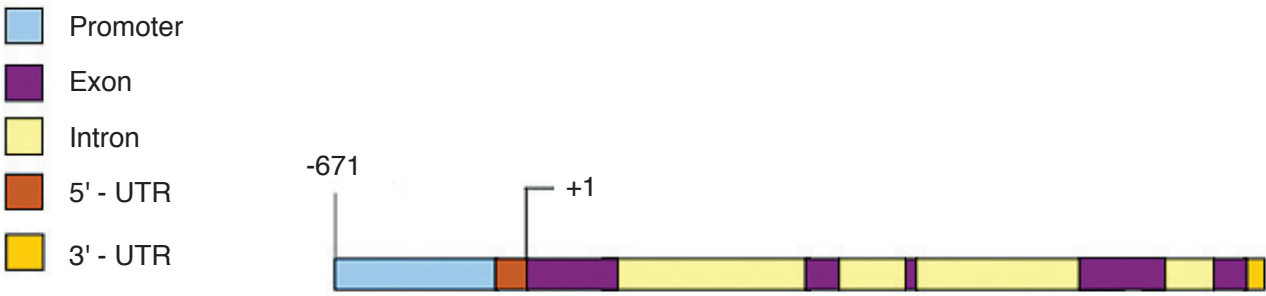

FFLI

B: Transient GUS expression
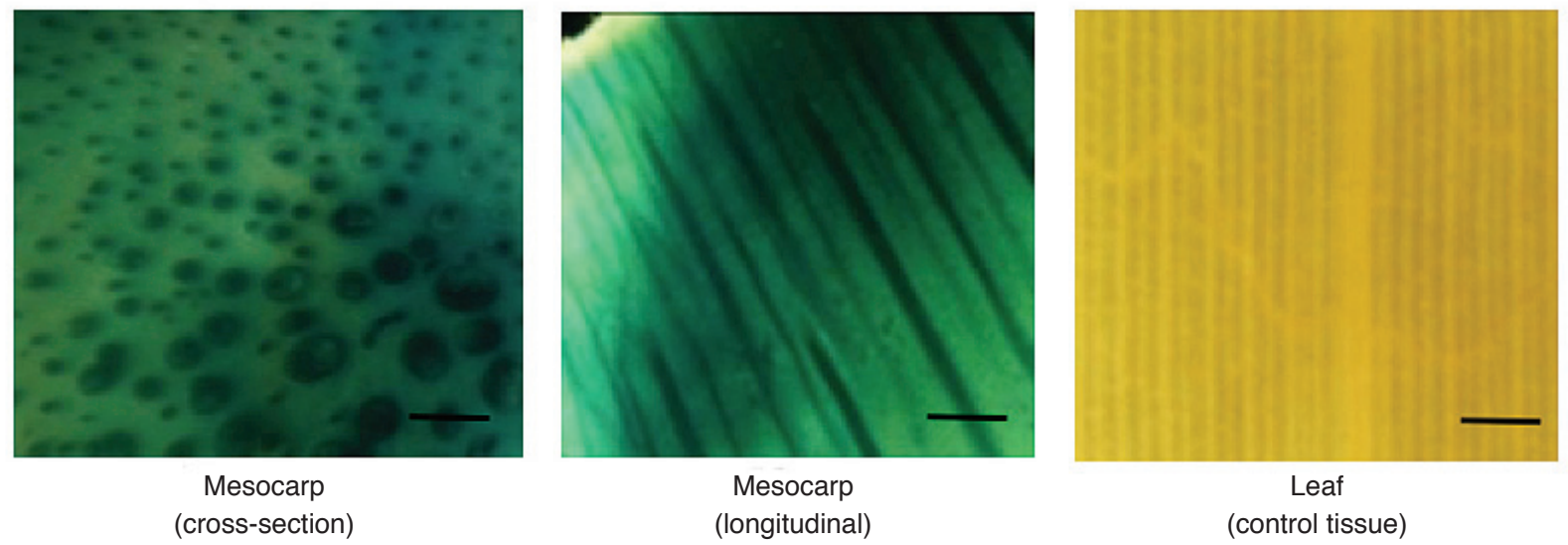

Figure 2. Characterisation and functional analysis of FLL1 gene and promoter. (A) Structure of the oil palm FLL1 promoter. (B) Transient $\beta$-glucuronidase (GUS) expression of FLL1 promoter::GUS (pFLL1GUS) expression profile in the mesocarp and leaf tissues of oil palm. Bar $=500 \mu \mathrm{m}$.

tissues and, can therefore potentially be used for genetic modification of oil palm for the focus product expressed in the mesocarp. These results are in agreement with northern blot and reverse transcription-polymerase chain reaction (RT-PCR) analysis where by the expression was detected throughout fruit development (Nurniwalis et al., 2015). This promoter has great potential for the production of novel oils and products.

\section{KERNEL-SPECIFIC PROMOTER}

\section{Seed Storage Protein Glutelin ( $p O P-K T 21)$ Promoter}

Following the isolation of the kernel-specific glutelin gene, the promoter region was isolated and fully characterised (Siti Nor Akmar et al., 2007; 2014). Detailed in silico sequence analyses showed that the promoter contained a GluB-JB (rice glutelin gene) motif that is essential to regulate endosperm-specific expression. This promoter was then analysed via transient expression assay to evaluate the functionality of the promoter. Constructed plasmid containing the pOP-KT21 promoter (GluP-EGFP) was bombarded into oil palm leaf discs, kernel and mesocarp tissue slices. GFP expression was detected in the kernel tissue slices bombarded with GluP-EGFP, but expression of GFP was not detected in the mesocarp and leaf tissues even though expression of co-bombarded CaMV 35S::GUS was detected (Siti Nor Akmar et al., 2014). Therefore, we suggest that the oil palm pOP-KT21 promoter is a functional promoter with enable expression in the kernel (Siti Nor Akmar et al., 2007; 2014).

\section{INDUCIBLE ROOT-SPECIFIC PROMOTER}

Further efforts have been made in isolating rootspecific promoters to be used in regulation of rootassociated agronomic traits such as nutrient uptake, tolerance to drought, flood or tolerance to pathogens (Jeong and Jung, 2015). Root-specific promoters have been extensively isolated from other crop species such as rice, barley and tomato (Yamamoto et al., 1991; Schünmann et al., 2004; Sasaki et al., 2012; Ueno et al., 2010; Puig et al., 2013; Kaur et al., 2014) and functionally characterised. In oil palm, a root-specific promoter could be used as part of the 
components to produce transgenic oil palm that is tolerant to Ganoderma or abiotic stresses such as flood and drought.

\section{Type 3 MT3-B: An Inducible Promoter for Root- specific Expression}

The genomic clone of MT3-B gene contains the coding region, two introns and the promoter sequence (687 bp) as shown in Figure $3 \mathrm{~A}$. Amongst the important regulatory motifs (putative) found in the promoter sequence are a metal responsive element, a GCC-box and a root-specific element (Zubaidah and Siti Nor Akmar, 2010).

The functionality of the MT3-B promoter to direct expression of transgenes to oil palm tissues was determined using GUS transient assay. GUS expression was only observed in oil palm root tissues but not in the spear leaves and mesocarp at 12 WAA (Figure 3B). In contrast, all tissues (leaf, mesocarp and root) bombarded with plasmid containing constitutive CaMV 35 S promoter (pCaMV35SGUS) showed GUS activity in all tissues tested (Figure $3 B)$. These results are in agreement with the earlier findings by Siti Nor Akmar et al. (2002) using Northern blot analysis.
Functional characterisation of the MT3- $B$ promoter was further carried out using Arabidopsis as a model system. GUS expression in all 12 transgenic plants driven by the $M T 3-B$ promoter was determined. Low GUS expression was observed in root and matured leaves and comparably higher expression was detected in cotyledon leaves (Figure $3 \mathrm{Ci}$ ). No expression was detected in other tissues tested. Whereas GUS expression was detected in most tissues of transgenic Arabidopsis lines carrying constitutive (CaMV 35S) promoter driving GUS (Figure 3Ci).

Further characterisation was carried out to determine the effects of metal ions to the promoter activity in transgenic Arabidopsis thaliana driven by the MT3-B promoter. In this study, metal ions in the form of $\left(\mathrm{ZnSO}_{4}\right.$ and $\left.\mathrm{FeSO}_{4}\right)$ were independently added to MS media and GUS expression was determined in transgenic Arabidopsis thaliana plants containing the MT3-B promoter:GUS fusion. Higher GUS expression was detected in transgenic Arabidopsis thaliana roots when the plant was treated with $\mathrm{Zn}^{2+}$ compared to untreated plants (Figure 3Cii). These findings were in line with results obtained from fluorometric assay (Zubaidah and Siti Nor Akmar, 2010) where we detected the increase of

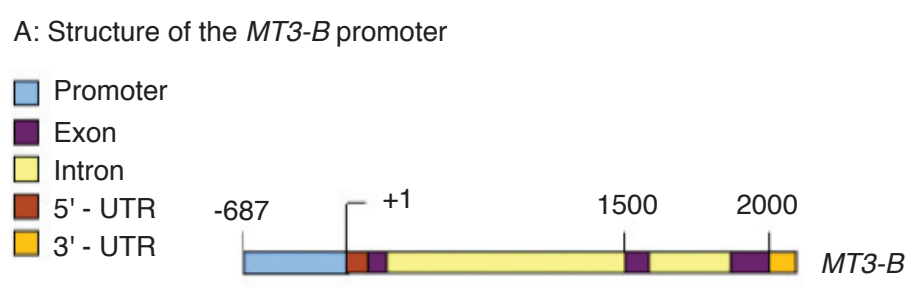

B: Transient GUS expression

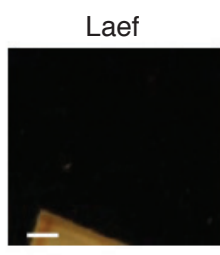

L1

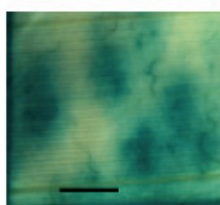

L2

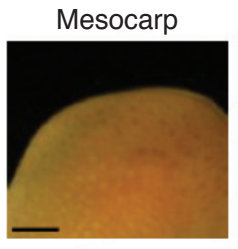

M1

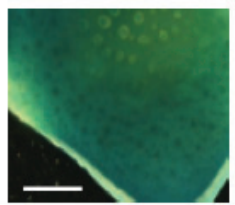

M2

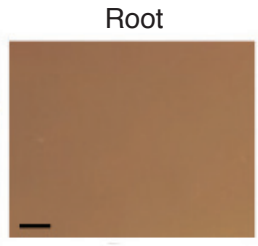

R1

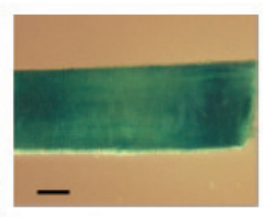

$\mathrm{R} 2$
MT3-B promoter

CaMV 355 promoter

C: (i) GUS expression in transgenic Arabidopsis

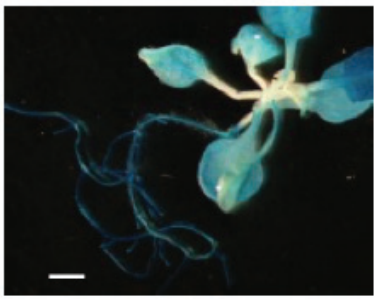

a

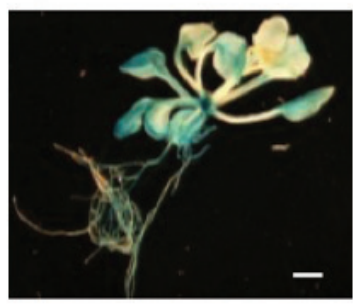

b

(ii) Effect of metal ions GUS expression in the root

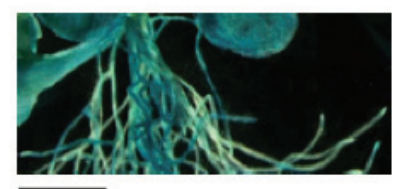

a

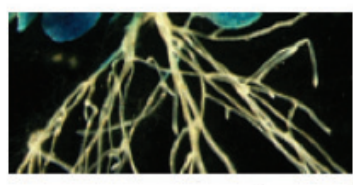

b

Figure 3. Characterisation and functional analysis of MT3-B promoter. A: Structure of the oil palm MT3-B promoter. B: Distribution of $\beta$-gluchronidase (GUS) activity in oil palm tissues bombarded with either CaMV 355 promoter (Li, M1 and R2) or MT3-B promoter (L2, M2 and R2). C (i): Comparison of GUS expression between transgenic Arabidopsis plants containing the constitutive CaMV 35S promoter (a) and the oil palm MT3-B promoter (b). C(ii): The effect of metal ion ( $\mathrm{ZnSO4}$ ) on the expression of the GUS gene in transgenic Arabidopsis root containing the oil palm MT3-B gene promoter(a) and the transgenic plant cultured on MS media without metal ions (b). Bar $=1 \mathrm{~mm}$. 
GUS expression (2.5- and 5-fold) in the roots with the presence of $80 \mu \mathrm{M}$ of $\mathrm{Fe}^{2+}$ and $\mathrm{Zn}^{2+}$ respectively. These observations suggest the hypothesis that the activity of the oil palm MT3-B promoter is stimulated by $\mathrm{Zn}^{2+}$ and $\mathrm{Fe}^{2+}$ in root tissues.

\section{LEAF-SPECIFIC PROMOTER}

Oil palm leaves have also been identified as a potential site for targeting the expression of novel metabolites that are impossible to produce via conventional breeding. The novel features of the leaf-specific promoter will prevent the accumulation of novel metabolites in the commodity oil which is extracted from mesocarp and kernel tissues. Furthermore, leaves are present throughout the plant life cycle thus this will enable early harvesting and continuous supply of novel metabolites (Chan, 2003). Manipulation of metabolic pathway in the leaf tissues for production of novel metabolites has been demonstrated previously such as production of biodegradable plastic or polyhydroxybutyrate (PHB) in Arabidopsis leaves (Poirier et al., 1992; Nawrath et al., 1994; Mittendorf et al., 1998).

\section{Light-harvesting Chlorophyll A/B Binding Protein Gene (LS01) Promoter}

The LS01 promoter was isolated using genome walking approach and the size of the isolated promoter was $932 \mathrm{bp}$ (Figure 4A) (Chan and Siti Nor Akmar, 2009; 2012; 2014). The transcription start site is located at $32 \pm 7 \mathrm{bp}$ upstream of the promoter sequence. This promoter is TATA-less but it has an initiator element (Inr motif) that could be used to direct basal transcription. A similar structure was also reported for the majority of nuclear encoded photosynthetic genes. It has been proposed that TATA-independent transcription mechanisms are crucial for regulated expression of photosynthesis nuclear genes (Nakamura et al., 2002). Furthermore, a few putative cis-acting elements responsive towards light, wounding, abscisic acid and heatshock were also found in the distal and proximal regions of the promoter.

Transient expression analysis of oil palm tissues bombarded with constructs containing the LSO1 promoter was conducted to assess the specificity of the promoter using GFP and GUS as reporter genes. Further characterisation was carried out using transgenic Arabidopsis system containing GUS reporter driven by oil palm LSO1 promoter. Based on GFP assay analysis, the expression was only detected in the leaf tissues bombarded with pLS01: GFP but not in mesocarp slices (Figure $4 B)$. Further confirmation was carried out using GUS as a reporter gene and as expected, the GUS expression was only observed in leaf tissues and no GUS expression was detected in the control tissue(mesocarp)(data not shown). In agreement with this finding, GUS expression analysis on transgenic Arabidopsis seedlings transformed with LS01 promoter showed specific expression in the leaf tissues but not in other tissues such as stem and root (Figure 4C). However for plants transformed with CaMV 35S::GUS construct, all the tissues stated above expressed GUS. Based on this study, Arabidopsis thaliana may be used as a model system for analysing oil palm leaf-specific promoter but there are limitations depending on the type of promoters and tissue dependent expression. This promoter is currently being used in the oil palm genetic engineering programme for the production of PHB and polyhydroxybutyrate-co-valerate (PHBV) in oil palm leaf tissues (Abdul Masani et al., 2009; Masani and Parveez, 2008; Hanin et al., 2016).

\section{CONSTITUTIVE PROMOTER}

Constitutive promoters are important for ensuring that a specific gene transferred into a plant will be functional in all plant tissues. They are also important for expressing reporter and selectable marker genes required for establishing a reliable transformation system for a particular plant species. A promoter that is derived from an oil palm native gene is likely to be more advantageous for oil palm as the efficiencies of promoters are sometimes species dependent. Moreover, the availability of a wide range of effective promoters would also make possible the introduction of multiple transgenes into plant cells with reduced risks of homologydependent gene silencing (Xiao et al., 2005).

\section{Ubiquitin Extension Protein Gene (uеp1) and Translationally Control Tumour Protein (TCTP) Gene Promoter}

The isolation of oil palm constitutive promoters was carried out through identification of constitutively expressed genes in oil palm. A number of EST clones were found to be constitutively expressed in all oil palm tissues by reverse +36 analysis. These putative clones were subjected to Northern analysis to further confirm their constitutive nature. Two cDNA clones that code for the ubiquitin extension protein gene (uep1) and TCTP genes were found to be constitutively expressed in oil palm (Masura et al., 2010; 2011). The promoter regions of these genes were isolated using genome walking and PCR approaches (Masura et al., 2010; 2011). Detailed sequence analysis have been performed using available databases and software to identify features in the gene architecture that could contribute to constitutive uep1 and TCTP expression. These promoters contain several motifs 
A: Structure of the $L S O 1$ gene promoter

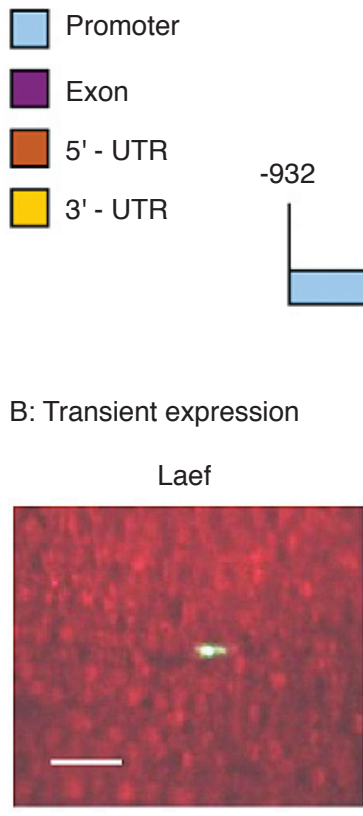

L1

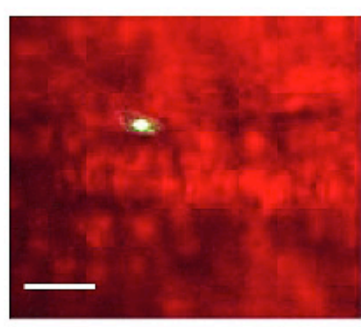

L2

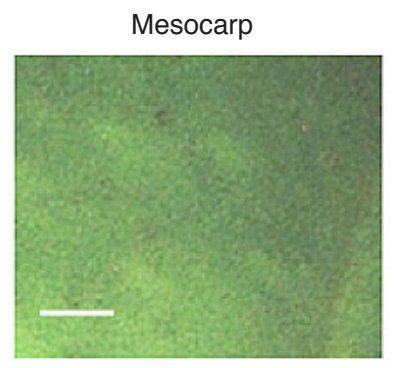

M1

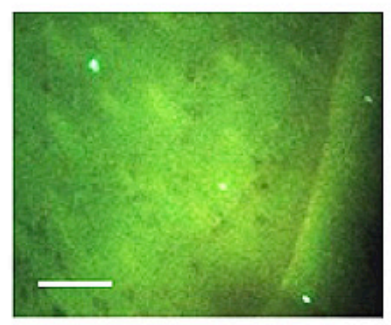

M2

LSO1

promoter

CaMV $35 S$

promoter

C: GUS expression in transgenic Arabidopsis

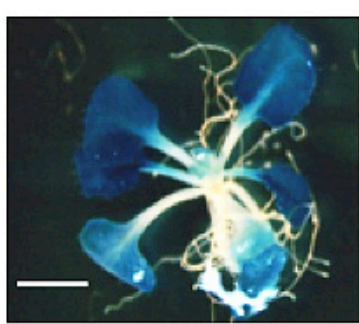

a

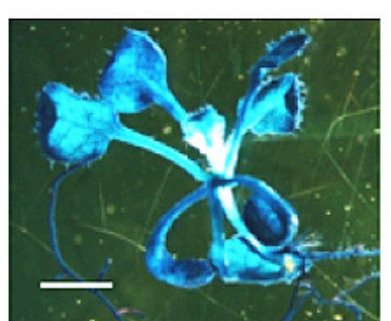

b

Figure 4. Characterisation and functional analysis of LS01 gene and promoter. (A) Genomic structure of the LS01 promoter. (B) Transient expression using histochemical GUS assay and green fluorescence protein (GFP) detection to confirm the leaf specificity of LS01 promoter. L1 and M1 represent GUS expression in leaf and mesocarp tissues derived using LSO1 promoter and L2 and M2, GUS expression derived from CAMV 35S promoter (C) $\beta$-gluchronidase (GUS) expression analysis in transgenic Arabidopsis thaliana to confirm the leaf specificity of LS01 promoter, a = constitutive promoter and LSO1 promoter. B, bar $=500 \mu \mathrm{m} ; \mathrm{C}$, bar $=5 \mathrm{~mm}$.

suggesting its potential multiple roles in hormonal signaling pathways, light regulation, biotic and abiotic stresses.

Functional characterisation of the isolated promoters were subsequently performed. Transformation vectors containing GUS as a reporter gene and nos terminator were constructed independently and designated as pUEP1 and pTCTP (Figures $5 A$ and $5 B$ ). The vectors were bombarded into oil palm tissues and tobacco leaves.
The functionality of the promoters was evaluated by comparing the GUS activity driven by native promoters with GUS activity driven by maize polyubiquitin (ubi1) and CaMV $35 S$ promoters. Results indicated that even though uep1 and TCTP demonstrated a high GUS activity, the strength of these promoters was slightly lower than the controls in some tissues, particularly to pAHC25 [Figures $5 \mathrm{~A}$ $(a-g)$ and $5 B(a-g)]$. The pAHC25, which is based on maize ubiquitin promoter has been shown to be the 
most effective promoter for oil palm (Chowdhury et al., 1997; Parveez et al., 2015b). In general, slight variation in the promoter strength was determined in the different tissues tested. Even though a strong constitutive promoter is certainly desired, sometimes the use of a weak promoter resulted in a higher transformation efficiency (Mengiste et al., 1997). It is hope that the isolation of uep1 and TCTP provides more alternative promoters for introducing multiple transgenes into plants. These promoters, by itself or after enhancement could be effective promoters for oil palm transformation, as well as for other dicotyledonous plants.

\section{POTENTIAL APPLICATION OF THE ISOLATED PROMOTERS AND THE WAY FORWARD}

Isolation of the three tissue-specific promoters, i.e., the MT3- $A$ and lipase class 3 promoters from mesocarp, and glutelin promoter from kernel, have the capacity to be used as genetic engineering tools to improve oil quality and yield. The availability of the oil palm genome database with abundant transcriptome information allows us to identify more potential oil palm candidate genes and promoters. We managed to discover 41 putative candidate mesocarp-specific genes from the oil palm genome information. Identification of these mesocarp- specific gene candidates provides a valuable basis for further research especially for oil palm genetic engineering work. Candidates of root-specific genes and genes that are predominantly expressed in root have been identified. These genes are heavy metal associated domain containing protein, peroxidase, glycine rich protein and cyp86. Root-specific promoters are potentially useful to develop plants with better tolerance to various types of abiotic stress such as soil types and soil $\mathrm{pH}$ and also microbial stresses. The study on leaf-specific promoter has contributed to the advancement of knowledge on promoter sequence and regulatory elements for controlling and driving leaf-specific gene expression in plants, particularly in the oil palm. The leaf-specific promoter is valuable for crop improvement and production of novel products through genetic engineering such as the production of insect resistant palms. Isolation of the two constitutive promoters derived from uep 1 and TCTP genes has contributed to the scientific community by providing new promoters for evaluation and testing in oil palm as well as other plants.

A total of seven oil palm derived promoters have been isolated and characterised (Table 1). With the availability of the oil palm genome data (Singh et al., 2013), more tissue-specific promoters can be isolated such as stem-specific promoter to control oil palm

(A)
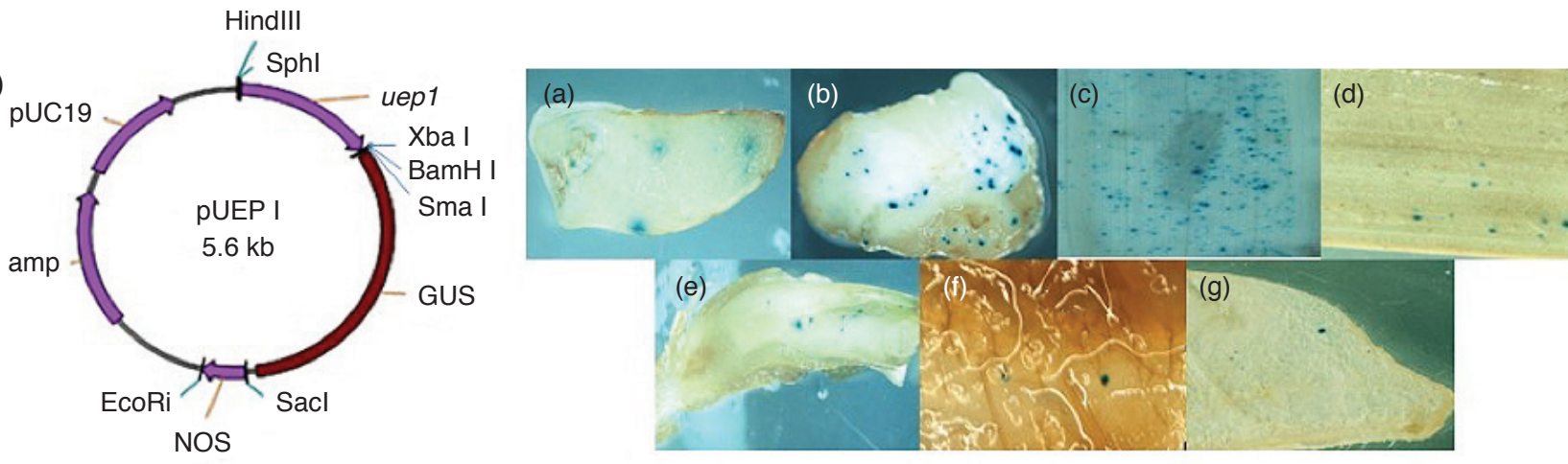

(B)
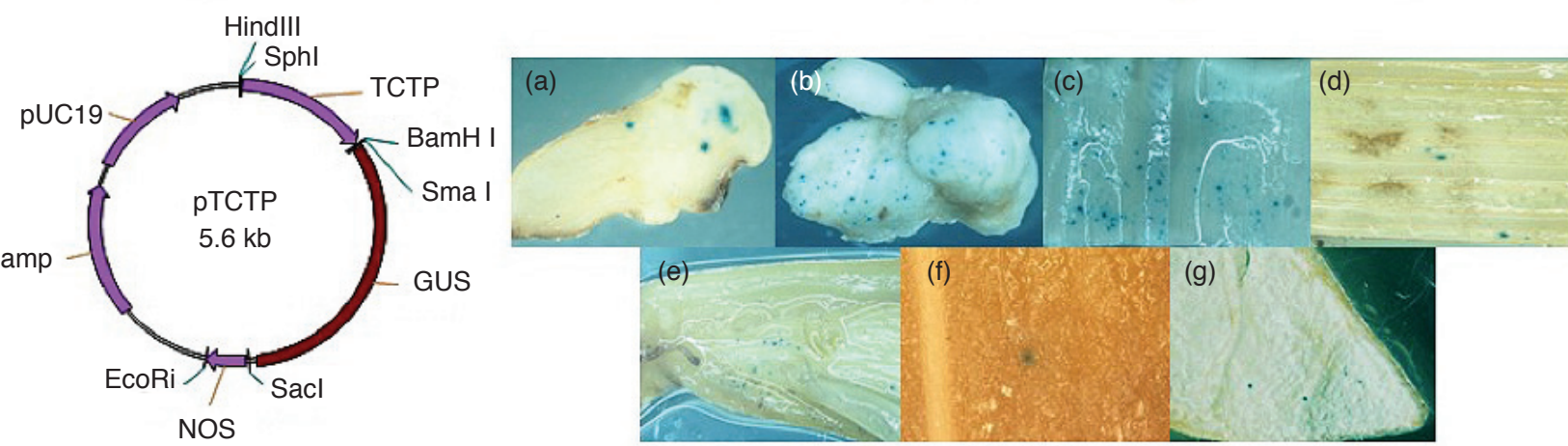

Figure 5. Isolation of constitutive promoters from oil palm. A) Transformation vectors containing uep1 promoter ( $p$ UEP1) and transient histochemical assay in various oil palm tissues and tobacco leaves bombarded with plasmid carrying $\beta$-gluchronidase (GUS) gene driven by uep1. (B) Transformation vectors containing TCTP promoter ( $p$ TCTP) and transient histochemical assay in various oil palm tissues and tobacco leaves bombarded with plasmid carrying GUS gene driven by TCTP. The GUS expression were detected in oil palm tissues, a: immature embryo, b: embryoid, c: young leaflet from mature palm, d: green leaves, e: plantlet stem, f: mesocarp and g: tobacco leaves. 
TABLE 1. LIST OF ISOLATED OIL PALM PROMOTERS AND POTENTIAL USES

\begin{tabular}{|c|c|c|c|}
\hline Type of promoter & Promoter name & Functional analysis & Potential usage \\
\hline \multirow[t]{2}{*}{ Messocarp-specific } & MT3-A & $\begin{array}{l}\text { Transient expression in oil palm tissues, } \\
\text { Siti Nor Akmar and Zubaidah (2008) }\end{array}$ & To improve oil quality \\
\hline & FLL1 & $\begin{array}{l}\text { Transient expression in oil palm tissues, } \\
\text { Nurniwalis et al. (2015) }\end{array}$ & \\
\hline Kernel-specific & $p O P-K T 21$ & $\begin{array}{l}\text { In situ hybridisation, Siti Nor Akmar } \\
\text { et al. (2014) }\end{array}$ & $\begin{array}{l}\text { Nutraceutical and } \\
\text { pharmaceutical products }\end{array}$ \\
\hline \multirow[t]{2}{*}{ Inducible root-specific } & MT3-B & $\begin{array}{l}\text { Transient expression in oil palm tissues, } \\
\text { Zubaidah and Siti Nor Akmar (2003) }\end{array}$ & Disease resistant palms \\
\hline & & $\begin{array}{l}\text { Arabidopsis thaliana, Zubaidah and } \\
\text { Siti Nor Akmar (2010) }\end{array}$ & \\
\hline \multirow[t]{2}{*}{ Leaf-specific } & LS01 & $\begin{array}{l}\text { Transient expression in oil palm tissues, Chan } \\
\text { et al. (2008) }\end{array}$ & Pest resistant palm, bioplastics \\
\hline & & Arabidopsis thaliana, Hanin et al. (2016) & \\
\hline Constitutive & Uep1 & $\begin{array}{l}\text { Transient expression in oil palm and } \\
\text { tobacco tissues, Masura et al. }(2010)\end{array}$ & Production of transgenic oil palm \\
\hline Constitutive & TCTP & $\begin{array}{l}\text { Transient expression in oil palm tissues } \\
\text { and tobacco, Masura et al. (2011) }\end{array}$ & \\
\hline
\end{tabular}

height, root-specific promoters that can utilised for root-associated agronomic traits and plant response to abiotic stresses and more mesocarp and kernel promoters for novel oil products. Isolation and characterisation of more than one tissue-specific promoters allow for more choices of promoters to be used to direct the accumulation of genetically engineered products to targeted tissues, as different promoters have different strengths and specificities to ensure stable expression of the transgene

\section{CONCLUSION}

Seven oil palm-derived promoters (two mesocarpspecific promoters, one kernel-specific promoter, one root-specific promoter, one leaf-specific promoter and two constitutive promoters) have been isolated and characterised. Findings from these studies, have generated knowledge through basic research that can be applied to develop the necessary innovations for the industry. The isolated promoters are potentially useful and can be used to improve traits as well as diversify the whole industry into a more sustainable and high income generating industry.

\section{ACKNOWLEDGEMENT}

We thank the Director-General of MPOB for permission to publish this article. We appreciate the help of Dr Abrizah Othman and Dr Ooi Siew Eng for critically reviewing this manuscript. We would also like to thank the laboratory members of Gene Function Group and Transgenic Technology Group for their assistance.

\section{REFERENCES}

ABDUL MASANI, M Y; AHMAD PARVEEZ, G K; DAYANG IZAWATI, A M; CHAN, P L and SITI NOR AKMAR, A (2009). Construction of PHB and PHBV multiple-gene vectors driven by an oil palm leaf-specific promoter. Plasmid, 62(3): 191-200.

AGIUS, F; AMAYA, I; BOTELLA, $\mathrm{M}$ A and VALUESTA, V (2005). Functional analysis of homologous and heterologous promoters in strawberry fruits using transient expression. J. Experimental Botany, 56 (409): 37-46.

CHAN, P L (2003). Pemencilan dan Pencirian Gene Spesifik Daun daripada Sawit (Elaeis guineensis). Master thesis, Universiti Kebangsaan Malaysia.

CHAN, P L; SITINOR AKMAR, A and ROOHAIDA, O (2008). Light-harvesting chlorophyll a/b binding protein (Lhcb) promoter for targeting specific expression in oil palm leaves. J. Oil Palm Res. Special Issue on Malaysia-MIT Biotechnology Partnership Programme: Oil Palm Metabolic Engineering, 2: 21-29.

CHAN, P L and SITI NOR AKMAR, A (2009). Leaf-specific chlorophyll $\mathrm{a} / \mathrm{b}$ binding protein gene promoter from oil palm. United States patent No.: 7629454 . 
CHAN, P L and SITI NOR AKMAR, A (2012). Leaf-specific chlorophyll $\mathrm{a} / \mathrm{b}$ binding protein gene promoter from oil palm. United States patent No.: 8263758.

CHAN, P L and SITI NOR AKMAR, A (2014). Leaf-specific chlorophyll $\mathrm{a} / \mathrm{b}$ binding protein gene promoter from oil palm. French patent No.: FR 2889540.

CHEAH, S C; SAMBANTHAMURTHI, R; ABDULLAH, S N A, ABRIZAH, O; MANAF, M A A; UMI SALAMAH, R and PARVEEZ, G K A (1995). Towards genetic engineering of oil palm (Elaeis guineensis Jacq.). Plant Lipid Metabolism (Kader, J C and Mazliak, P eds.). Kluwer Academic, Dordrecht.

CHOWDHURY, M K U; PARVEEZ, G K A and NORIHAN, MS (1997). Evaluation of five promoters for use in transformation of oil palm (Elaeis guineensis Jacq.). Plant Cell Reports, 16: 277-281.

HANIN, A N; MASANI, A M Y and PARVEEZ, G K A (2016). Evaluation of oil palm leaf-specific promoter (LSP1) activity for expressing PHB genes in Arabidopsis thaliana. J. Oil Palm Res. Vol. 28: 1-9.

JEONG, H J and JUNG, K H (2015). Rice tissue specific promoters and condition-dependent promoters for effective translational application. J. Integrative Plant Biology, 57(11): 913-924.

KAMALDINI, $\mathrm{H} ;$ ABDULLAH, S N A and MAHERAN, A A (2011). Metal inducible activity of the oil palm metallothionein-like gene promoter (MT3-A) in prokaryotes. J. Bioscience and Bioengineering, 111(2): 217-225.

KAUR, C; MUSTAFIZ, A; SARKA, A K; ARIYADASA, T U; SINGLA-PAREEK, $S \mathrm{~L}$ and SOPORY, S K (2014). Expression of abiotic stress inducible ETE1-like protein from rice is higher in roots and is regulated by calcium. Physiol Plant, 152: $1-16$.

MASANI, A M Y and PARVEEZ, G K A (2008). Development of transformation vectors for the production of high oleate transgenic oil palm. Electronic J. Biotechnology [online]. 15 July 2008, Vol. 11 No. 3

MASANI, A M Y; HO, C L and PARVEEZ, G $\mathrm{K}$ A (2008). Construction of $\mathrm{PHB}$ and PHBV transformation vectors for bioplastics production in oil palm. J. Oil Palm Res. Special Issue on MalaysiaMIT Biotechnology Partnership Programme: Oil Palm Metabolic Engineering, 2: 37-55.

MASANI, A M Y; NOLL, G; PARVEEZ, G K A; SAMBANTHAMURTHI, $\mathrm{R}$ and PRUEFER,
D (2014). Efficient transformation of oil palm protoplasts by PEG-mediated transfection and DNA microinjection. PLoS ONE 9(5): e96831. DOI: 10.1371 /journal.pone.0096831.

MASLI, D I A; PARVEEZ, G K A and MASANI, A M Y (2009). Transformation of oil palm using Agrobacterium tumefaciens. J. Oil Palm Res. Vol. 21: 643-652.

MASURA, S S; PARVEEZ, G K A and ISMANIZAN, I (2010). Isolation and characterization of oil palm constitutive promoter derived from ubiquitin extension protein (uep1) gene. New Biotechnology, 27: 289-299.

MASURA, S S; PARVEEZ, G K A and LESLIE, L E T (2011). Isolation and characterization of an oil palm constitutive promoter from a translationally control tumor protein (TCTP) gene. Plant Physiology and Biochemistry, 40: 701-708.

MENGISTE, T; AMEDEO, P and PASZKOWSKI, J (1997). High-efficiency transformation of Arabidopsis thaliana with a selectable marker gene regulated by the T-DNA 1' promoter. Plant J., 12: 945-948.

MITTENDORF, V; ROBERTSON, E J; LEECH, R M; KRUGER, N; STEINBUCHEL, A and POIRIER, $Y$ (1998). Synthesis of medium-chain-length polyhydroxyalkanoates in Arabidopsis thaliana using intermediates of peroxisomal fatty acid $\beta$-oxidation. Proc. Natl. Acad. Sci. USA., 95: 13397-13402.

MOHD BASRI, W; SITI NOR AKMAR, A and HENSON, I E (2005). Oil palm - achievements and potential. Plant Prod. Sci., 8(3): 288-297.

NAKAMURA, M; TSUNODA, T and OBOKATA, J (2002). Photosynthesis nuclear genes generally lack TATA-boxes: A tobacco photosystem I gene responds to light through an initiator. Plant J., 29(1): 1-10.

NAWRATH, C; POIRIER, $\mathrm{Y}$ and SOMERVILLE, C (1994). Targeting of the polyhydroxybutyrate biosynthetic pathway to the plastids of Arabidopsis thaliana results in high levels of polymer accumulation. Proc. Natl. Acad. Sci. USA., 91: 1276012764.

NURNIWALIS, A W; SUHAIMI, N; SITI NOR AKMAR, A; AMINAH, S and MOHAMAD ARIF M A (2008). Gene discovery via expressed sequence tags from the oil palm (Elaeis guineensis Jacq.) mesocarp. J. Oil Palm Res.Vol. 2: 87-96.

NURNIWALIS, A W; ZUBAIDAH, R; SITI NOR AKMAR, A; ZULKIFLI, H; MOHAMAD ARIF, M A; MASSAWE, F J; CHAN, P L and PARVEEZ, G K 
A (2015). Genomic structure and characterization of a lipase class 3 gene and promoter from oil palm. Biologia Plantarum, 59(2): 227-236.

OIL WORLD (2013). Oil World and World 2013. ISTA, Mielke, Hamburg.

OMIDVAR, V; SITI NOR AKMAR, A; IZADFARD, A; HO, C L and MAZIAH, M (2010). The oil palm metallothionein promoter contains a novel AGTTAGG motif conferring its fruit-specific expression and is inducible by abiotic factors. Planta. DOI: 10.1007 / s00425-010-1220-z.

PARVEEZ, G K A; RASID, O A and MASANI, A M Y (2015a). Biotechnology of oil palm: strategies towards manipulation of lipid content and composition. Plant Cell Rep., 34: 533-543.

PARVEEZ, G K A; BAHARIAH, B; AYUB, N H; MASANI, A M Y; RASID, O A; TARMIZI, A $\mathrm{H}$ and ISHAK, $\mathrm{Z}$ (2015b). Production of polyhydroxybutyrate in oil palm (Elaeis guineensis Jacq.) mediated by microprojectile bombardment of PHB biosynthesis genes into embryogenic calli. Front. Plant Sci., 6: 598. DOI: 10.3389/fpls.2015.00598.

PARVEEZ, G K A; ABRIZAH, O; NURHAFIZAH, $\mathrm{R}$ and BAHARIAH, B (2010). Functional analysis of oil palm palmitoyl-ACP thioesterase (Fat B) via down regulation in model plant. J. Oil Palm Res.Vol. 22: 803-813.

PARVEEZ, G K A (2003). Novel products from transgenic oil palm. AgBiotechNet., 5 (ABN113): 1-8.

PARVEEZ, G K A; RASID, O; ZAINAL, A; MASRI, M M; MAJID, N A; FADILLAH, H H; YUNUS, A M M and CHEAH, S C (2000). Transgenic oil palm: production and projection. Biochemistry Society Transactions, 28 (6): 969-972.

PARVEEZ, G K A; RAVIGADEVI, S; ABDULLAH, S N A; OTHMAN, A; RAMLI, U S; RASID, O; MASRI, M M and CHEAH, S C (1999). Production of transgenic oil palm - current success and future considerations. Proc. of the PIPOC 1999 International Palm Oil Congress - Agriculture. PORIM, Bangi. p. 3-13.

POIRIER, Y; DENNIS, D E; KLOMPARENS, K and SOMERVILLE, C (1992). Polyhydroxybutyrate, a biodegradable thermoplastics, produced in transgenic plants. Science, 256: 520-523.

PUIG, J; MEYNARD, D; KHONG, G N; PAULUZZI, G; GUIDERDONI, E and GANTET, P (2013). Analysis of the expression of the AGL17 like clade of MADS-box transcription factor in rice. Gene Expression Pattern, 13: 160-170.
SASAKI, A; YAMAJI, N; YOKOSHO, A and MA, J F (2012). Nramp5 is a major transporter responsible for manganese and calcium uptake in rice. Plant Cell, 24: 2155-2167.

SCHAART, J G; SALENTIJN, E J M and KRENS, F A (2002). Tissue-specific expression of the â-glucuronidase reporter gene in transgenic strawberry (Fragaria ananassa) plants. Plant Cell Report, 21: 313-319.

SCHÜNMANN, P H D; RICHARDSON D; VICKERS, C E and DELHAIZE, E (2004). Promoter analysis of the barley Pht1;1 phosphate transporter gene identifies regions controlling root expression and responsiveness to phosphate deprivation. Plant Physiol., 136(4): 4205-4214.

SINGH, R; LOW, E-T; OOI, LC-L; MEILINA O-A; TING, N-C; JAYANTHI, N; RAJANAIDU, N; AMIRUDDIN, M D; ROSLI, R; MANAF, M A A; CHAN, K-L; HALIM, M A; AZIZI, N; LAKEY, $\mathrm{N}$; SMITH, S W; BUDIMAN, $\mathrm{M}$ A; HOGAN, M; BACHER, B; VAN BRUNT, A; WANG, C; ORDWAY, J M; SAMBANTHAMURTHI, $\mathrm{R}$ and M ARTHIENSSEN, R (2013). The oil palm SHELL gene controls oil yield and encodes a homologue of SEODSTICK. Nature, 500 (7462): 340-344.

SITI NOR AKMAR, A and ZUBAIDAH, R (2007). Regulatory sequences for regulation of gene expression in plants and other organisms, and compositions, products and methods related thereto. Patent No. US7, 173,120 B2.

SITI NOR AKMAR, A and ZUBAIDAH, R (2009). Regulatory sequences for regulation of gene expression in plants and other organisms, and compositions, products and methods related thereto. Malaysian patent No. MY-137397-A.

SITI NOR AKMAR, A and ZUBAIDAH, R (2008). Mesocarp-specific metallothionein-like gene promoter for genetic engineering of oil palm. J. Oil Palm Res. Vol. 2: 1-8.

SITI NOR AKMAR, A; CHEAH, S C and MURPHY, D J (2002). Isolation and characterisation of two divergent type 3 metallothioneins from oil palm, Elaeis guineensis. Plant Physiology and Biochemistry, 40: $255-263$

SITI NOR AKMAR, A; CHEAH, S C and NURNIWALIS, A W (2007). Expression regulatory elements. Malaysian patent No. PI 20070394.

SITI NOR AKMAR, A; CHEAH, S C and NURNIWALIS, A W (2014). Expression regulatory elements. United States patent No. US 8,791,330 B2. 
SITI NOR AKMAR, A; RAVIGADEVI, $S$ and AHMAD PARVEEZ, G K (2001). Genetic modification of oil palm producing novel oils. Proc. of the 2001 PIPOC International Palm Oil Congress Agriculture. p. 18-30.

TERZAGHI, W B and CASHMORE, A R (1995). Light-regulated transcription. Annual Review of Plant Physiology and Plant Molecular Biology, 46: 445-474.

UENO, D; YAMAJI, N; KONO,J; HUANG, C F; ANTO, T; YANO, M and MA, J F(2010). Gene limiting cadmium accumulation in rice. Proc. Natl. Acad. Sci. USA, 107: 16500-16505.

XIAO, K; ZHANG, C; HARRISON, $\mathrm{M}$ and WANG, $Z-Y(2005)$. Isolation and characterization of a novel plant promoter that directs strong constitutive expression of transgenes in plants. Mol. Breed., 15: 221-231.

YAMAMOTO, Y T; TAYLOR, C G; ACEDO, G N; CHENG, C-L and CONKLING, M A (1991). Characterization of cis-acting sequences regulating root-specific gene expression in tobacco. Plant Cell, 3: 371-382.

ZUBAIDAH, R and SITI NOR AKMAR, A (2003). Development of a transient promoter assay system for oil palm. J. Oil Palm Res. Vol. 15 (2): 62-69.

ZUBAIDAH, R and SITI NOR AKMAR, A (2010). Functional characterization of the oil palm type 3 metallothionein-like gene (MT3-B) promoter. Plant Molecular Biology Reporter, 28: 531-541. 